\title{
What Happened to Kapp's Theory of Social Costs? A Case of Metatheoretical Dispute and Dissent in Economics
}

\section{Vítor Neves}

Faculty of Economics and Centre for Social Studies, University of Coimbra, Coimbra, Portugal

\begin{abstract}
In the early 1970s Wilfred Beckerman and K. William Kapp engaged in a serious dispute. Although it focused on social costs, the dispute raised issues about the very foundations of economics. The differences in approach to social costs that this dispute exposed were so deep-rooted as to preclude (or at least hinder) any possibility of constructive dialogue. This article argues that the subsequent 'conspiracy of silence' against Kapp should be understood in terms of Kapp's very different conception of economics as a social science. This issue is relevant to a broader discussion about the boundaries of pluralism in economics-how these boundaries are drawn and the conditions for a constructive dialogue among economists and with other social scientists.
\end{abstract}

\section{ARTICLE HISTORY}

Received 30 October 2015

Accepted 28 June 2016

\section{KEYWORDS}

Dissent; externalities; Kapp; pluralism; social costs

\section{JEL CODES}

B41; B31

Disagreement, controversy, and dissent are an integral part of science, without which it cannot be understood... they reveal things about science that would otherwise remain either concealed or obscured (Backhouse 2004, p. 262).

The most serious reason for persistent disagreements and communication problems among economists is that economists are in a bunch of conversations and talking across them is problematic if not impossible (Klamer 2007, p. 127).

\section{Introduction}

In the early 1970s the neoclassical environmental economist Wilfred Beckerman and the institutionalist K. William Kapp engaged in a serious dispute that focused on environmental disruption and social costs. However, at its core was a discussion about the very foundations of economics: namely, the (in)adequacy of the logic of choice by conventional economic theory to deal with the complex set of interdependencies and cumulative chain of effects giving rise to social costs in a market economy and the consequent search for a desirable rational use of resources, the appropriateness or otherwise of price indicators to support decisions on the best course of action to follow, and the relevance and adequacy of 
the compensation principle of conventional welfare economics as a criterion of decision making. Ultimately, it was a metatheoretical fight about the character of economics.

At the origin of the dispute was Kapp's (1970) paper, 'Environmental Disruption and Social Costs: A Challenge to Economics', whose general theme Beckerman said he could not accept without protest. Beckerman and Kapp confronted each other's position during the 'Symposium on Political Economy of Environment: Problems of Method', which took place in Paris, 5-8 July 1971 at the Maison des Sciences de l'Homme. Beckerman's critique and Kapp's rebuttal were subsequently published in the journal Social Science Information (Beckerman 1972; Kapp 1972).

In spite of the relevance and significance of the issues discussed, the dispute ended at the Paris Symposium without any further exchange. Kapp was an acknowledged contributor to the discussion on social costs. ${ }^{1}$ However, his theory became largely forgotten in the mainstream conversation on negative externalities and is generally ignored by historians of economic thought. The discourse on social costs has become grounded in two dominant approaches: the Pigovian and the Coasean (Aslanbeigui and Medema 1998; Berger 2012).

Kapp dedicated most of his academic work to the problem of social costs. ${ }^{2}$ The Social Costs of Private Enterprise (SCPE), his seminal book on the subject-originally published in 1950, reprinted in 1963 with a new title, The Social Costs of Business Enterprise, and translated into several languages (Kapp 1950, 1978 [1963])—was the first of a long series of works on social costs he wrote over more than a quarter of a century. ${ }^{3}$ The richness, originality and relevance of his contribution should not need particular emphasis. Kapp produced highly innovative work, which in various ways anticipated topics and issues whose relevance would be recognized only much later. Thus, it comes as no surprise that there is a persistence of interest in Kapp's work among some circles of non-mainstream economists or a significant revival of interest over the last few years. ${ }^{4}$

It has been argued that Kapp's exclusion from the mainstream discourse on social costs can be explained by a market fundamentalist bias against his radical critique of the system of business enterprise. Sebastian Berger $(2012,2013)$ claims that it was the result of a deliberate, not innocent, 'ignore' strategy undertaken by what, following Mirowski and Plehwe (2009), he calls the 'neoliberal thought collective'-Knight, Coase, Stigler, Calabresi, Buchanan and Beckerman-in order to change the discourse on social costs. Knight's (1951) early criticism of Kapp, according to which Kapp's reflections in SCPE sounded like 'socialistic critique and propaganda', seems to offer some support for such a position. This article, however, argues that a political-ideological explanation of Kapp's marginalisation is incomplete and partial.

There are profound differences between the approaches of Kapp and conventional economics to social costs. Beckerman's (1972) critique of Kapp and the latter's rebuttal clearly establish the deep gulf distancing Kapp from the conventional approach. In

\footnotetext{
${ }^{1}$ See, for example, Beckerman (1972, p. 7), Ayres and Kneese (1969, p. 282) and Coddington (1970, p. 596).

${ }^{2}$ 'When you ask me how my study of social costs came about, you are almost asking me to tell you the story of my life' (Kapp 2016, p. 119). For biographical details, see the introductions to Steppacher, Zogg-Walz, and Hatzfeldt (1977) and Kapp $(1985,2011)$.

${ }^{3}$ Kapp's concern with social costs dates from 1936 and goes back to his PhD dissertation, in the context of the debates on planning, economic calculation and the consequent discussion of the rationality of economic decisions. (See Kapp 2016, pp. 22-34, 119-120.)

${ }^{4}$ See, for example, Elsner, Frigato, and Ramazzoti (2006), Kapp (2011, 2016), Gerber and Steppacher (2012) and Ramazzotti, Frigato, and Elsner (2012).
} 
addition to the obvious theoretical departures, the Kapp-Beckerman dispute exposed significant differences in vision and modes of thought, ${ }^{5}$ in their conceptions of the nature and scope of economic analysis and of how social costs are conceived and (theoretically and practically) dealt with. In a number of respects, it is discernible that those differences are so deep-rooted and involve so many paradigmatic incommensurabilities that constructive dialogue becomes hardly possible. Divergences have to do with beliefs located at the (Lakatosian) hard-core level. These beliefs are so entrenched in people's minds that they do not become the subject of controversy; they are simply ignored or dismissed.

If this is true then it is not difficult to understand the 'conspiracy of silence' surrounding Kapp. ${ }^{6}$ This is due, at least to a significant degree, to his rather different conception of economics as a social science; and to his failure to 'think like an economist' (in the sense this expression usually assumes in introductory conventional economics textbooks). This will be the focus in the remainder of this article. In Section Two the main threads of Kapp's conception of social costs are presented. Section Three highlights the main topics of the Kapp-Beckerman dispute. In Section Four it is shown why Kapp has been placed on the periphery of the economics profession. Section Five concludes. This discussion establishes the relevance of determining the boundaries of pluralism in economics-how these boundaries are drawn and the conditions for a constructive dialogue among economists and with other social scientists.

\section{Kapp's theory of social costs}

In the paper that was the genesis of the dispute with Beckerman, Kapp was clear about his different understanding of the concept of social costs and why he thought the conventional framework, and the usual tools of conventional economics, were 'ill-adapted and in fact irrelevant' to grasping them (Kapp 1970, p. 839).

Since SCPE, and in subsequent works, Kapp showed that social costs were an inexorable product of the system of business enterprise, involving a complex set of interdependencies and cumulative chains of causation (with unavoidable distributive and political dimensions). He questioned the search for solutions to environmental disruption and social costs through markets or economic calculations based on market prices and equilibrium analysis.

In various respects Kapp's theory of social costs represents a break with the Pigovian and Coasean approaches. According to Kapp, social costs are unpaid (or uncompensated), pervasive harmful effects of productive activities and business practices, intrinsically linked to the logic of decision making in a system of business enterprise. They are unaccounted for tangible and intangible costs (by the agents who produce them), transferred (shifted) to and borne by third parties, the community as a whole, or future generations. These costs cover a very broad range of environmental and social diseconomies, including such diverse and heterogeneous aspects as: environmental pollution (in its various forms); the depletion of renewable resources and the exhaustion of non-renewable resources; urban congestion and inadequate housing conditions; deteriorating working conditions;

\footnotetext{
${ }^{5}$ The meaning of these concepts is discussed in Section Four.

${ }^{6}$ I adopt here the expression used by Kapp himself, in his discussion with Beckerman, regarding a frequent attitude of mainstream economists against their critics (Kapp 1972, p. 20).
} 
workplace accidents and occupational diseases; the harmful effects of technological change; enforced and uncompensated adaptations to structural changes; economic instability and unemployment; and the sacrifice of individuals' well-being to the rhythms of work, interests and demands of the profit-oriented economic machine. Social costs thus have to do with a wide "variety of "diseconomies", increased risks and uncertainties which may extend far into the future' (Kapp 1963, p. 185).

Kapp usually referred to these costs as a product of entrepreneurial action (either by private or public firms). However, as he acknowledged, social costs may arise also as a result of public decision making. Thus, Kapp suggested a broader definition of social costs to include all 'damages and harmful effects of economic decision-making (private and public) rather than as a result of entrepreneurial action alone' (Kapp 1983 [1965], p. 10, original emphasis). ${ }^{7}$

For Kapp, it is irrelevant whether the damage caused by the action of an agent, measured as losses in well-being of those who suffer them, are greater or lesser than the advantages they bring to those who produce them (a central question in the framework of the conventional analysis of externalities). Kappian social costs are, as Franzini (2006) emphasises, violations of basic social rights, or even a reversal of these rights, perpetrated by market capitalism, whether they occur in a Pareto-efficient context or not. The social damage, even if less than the gains for companies, still represents a violation of social rights and for this very reason is no less important.

Some distinctive features of Kapp's understanding of social costs are described below.

\subsection{Social costs are to be considered as an inevitable outcome of profit-oriented economies}

The existence of social costs is fundamentally due to the fact that the search for profit leads to a minimisation of the private costs of production. In minimising their internal costs, companies tend to transfer to third parties and the community in general, and effectively maximise social costs (that is, the portion of the total costs usually termed external costs in the conventional economics literature). The free operation of the market promotes the 'externalisation' or, as he preferred to call it, the large scale shifting of a significant part of the total cost of production to the community (the conversion of external costs into social costs). ${ }^{8}$ Rather than an undesirable co-product, a secondary effect of a main activity (as it is usually assumed), social costs are an intrinsic and necessary feature of profit-based economies. The capitalist economy is, in Kapp's (1978 [1963], p. 268) words, an 'economy of unpaid costs'.

\subsection{Social costs involve asymmetric and involuntary relationships and power}

As a rule, causal processes leading to social costs involve non-market, asymmetric and often involuntary relationships, shaped by relatively powerful entities that impose their interests on the economically and politically weaker sectors of society. The possibilities

\footnotetext{
${ }^{7}$ See also the new introduction to the 1971 edition of SCPE (Kapp 1950, p. xvi).

${ }^{8}$ 'By minimizing their internal costs [business enterprises] tend to shift and actually maximize the social costs' (Kapp 1978 [1963], p. 76).
} 
of resistance to the shift of costs by negotiating conflicting interests-following a Coasean line of thought —are, in Kapp's view, limited (1978 [1963], pp. 267-268).

Kapp contests the idea that social costs can, in general, be reasonably conceived within a framework of bilateral and reciprocal relations. Economic actors have different opportunities to access the relevant information and different capacities for controlling or even manipulating this information, as well as unequal bargaining power (Kapp 1977, p. 531). The problem of social costs includes a dimension of power, and therefore politics - ignored by mainstream conventional economic theory-without which it cannot be fully understood.

The fact that part of the costs of production can be shifted to third persons or to society as a whole is merely another way of saying that costs and hence profits depend at least to some extent on the power of the individual firm to do so. In short, what the conventional theory treats as given is in fact already the result of a constellation of market or non-market interdependencies between units of a heterogeneous character and with different degrees of economic control and domination (Kapp 1969, p. 335; emphasis added).

Elsewhere Kapp states:

Economic history and, more particularly, the history of economic development and social legislation in many advanced countries, could be written (or re-written) as the history of the success or failure to reduce the social costs of production (1983 [1965], p. 2).

Kapp's theory of social costs is indeed a 'social conflict theory' (Berger 2016, p. 7): the extent of social costs shows how (un)successful the struggle against the socialisation of private costs has been.

\subsection{The complex and cumulative character of social costs}

Social costs develop in the context of complex causal processes that link production, the natural and social environments, and individuals. They are the result of the combined effects of a plurality of (economic and non-economic) factors and systemic interdependencies that govern socioeconomic processes. These have a dynamic, self-reinforcing and cumulative (or circular) character. Any reasonable attempt to understand social costs (and minimise their effects) will require an approach that fully recognises (i) the open nature of socioeconomic systems, and (ii) the circular and cumulative nature of those causal processes (Kapp 1976). Their cumulative nature demands that consideration be given to critical thresholds (or critical zones), which is lacking in conventional economic analyses, on the basis of which social costs acquire a new relevance and meaning. Linear cause and effect mechanisms and theoretical approaches based on the conventional notion of equilibrium thus prove inadequate for analysing social costs.

\subsection{The solution for social costs}

For Kapp, social costs are a large-scale problem of the 'system of markets under capitalism', not an undesirable anomaly that occurred in individual markets (Lee 2013, p. 1). Their origin lies in the principle of investment for profits and corresponds to gaps between, on the one hand, the actual gratification of social needs and requirements of human life and, on the other hand, normative (but 'empirically and objectively' 
ascertainable) 'social minima' (e.g. minimum standards of public health, medical care and education) and 'maximum tolerable levels' (critical thresholds) of environmental and social disruption (Kapp 1965a, pp. 67-68, 75; 1974, pp. 129-130; 2011, pp. 92-93). They are systemic in nature. As such, he believed, social costs can only be minimised through appropriate institutional reforms and ex ante social controls rather than ex post facto tax and subsidy remedies (as Pigou suggested) or the assignment of appropriate property rights and private bargaining (as Coase seemed to believe). Planning-based upon the definition of social minima and a principle of precautionary action under uncertainty-and the democratic establishment of priorities and the resolution of conflicting interests and needs (through collective deliberation and choice), constituted, in Kapp's view, the appropriate way to deal with social costs.

As Lee $(2013$, p. 2) notes, while the core of Kapp's analysis involved a rejection of neoclassical mainstream theory, his 'policy implications involved a rejection of capitalism'.

\section{The focus of the Kapp-Beckerman dispute}

Anyone minimally acquainted with the standard economics textbook view of externalities will readily note the significant differences between the approaches of Kapp and conventional economics to the conceptualisation of social costs. However what most infuriated Beckerman, and led him to write an unpleasant attack on Kapp's (1970) 'challenge to economics', was the latter's critical stance towards 'the conventional framework and tools of economic theory', regarded as 'narrow', 'ill-adapted' and 'irrelevant' for the analysis of environmental disruption and social costs (Beckerman 1972, p. 8).

Beckerman basically put forth a strong defence of contemporary conventional economics and of its important achievements even if, he acknowledged, it 'does not have any ready-made answers to even the narrowly economic aspects of environmental pollution, let alone to the much wider problems of the standard of life and so on' (ibid, p. 15). More specifically, he praised the various conceptual and analytical developments in economics-'central to the problem of the environment' (ibid, p. 10) - at the level of the theory of externalities, the social welfare function, the study of the effects of taxes and subsidies on the optimal allocation of resources, the treatment of the problems of discounting future costs and benefits and of risk, all considered to 'have reached a state of great generality' ( $i b i d)$. In his view, Kapp's critique of standard economics was 'much too vague' (ibid, p. 8), nothing more than 'unsubstantiated assertions and adjectives' (ibid ) with no positive examples of the purported failures of conventional economics, and he charged Kapp with not suggesting 'anything better to put in its place' (ibid, p. 11). In particular, he contested Kapp's rejection of price indicators (actual market prices or shadow prices) as an adequate means to evaluate social costs and the latter's suggestion that these were evaluated in real terms. In his view, 'some attempt must be made to arrive at some measure of the damage done by pollution of various kinds', but, he argued, although this raises 'very difficult problems of valuation ... no means of making [choices] that is superior to the methods being developed within the framework of conventional economics has yet been discovered' (ibid, pp. 12-13).

Kapp's rebuttal focused on two different, albeit closely related, central aspects:

(1) The inadequacy of the 'logic of choice' and 'optimization' to deal with the search for a desirable rational use of resources in terms of actual satisfaction of substantive needs 
and requirements of human life (1972, p. 19). Attention therefore went to a discussion of substantive versus formal rationality (and social versus market efficiency). Let us call this the rationality issue.

(2) The inappropriateness of monetary valuation based on market prices to support decisions on the most desirable course of action to follow and the logically defective and operationally ineffective' use of the compensation principle of welfare theory as a 'cognitively responsible' criterion of decision ('the question of the adequacy of evaluating environmental goals and values in terms of the individual's willingness to pay or accept compensation') (pp. 23, 27, 18). Let us call this the problem of valuation.

Beckerman's views on economics are conventional and thus well known, requiring no particular elaboration. We will focus on these two issues from Kapp's perspective.

\subsection{The rationality issue}

In his public inaugural lecture at the University of Basel, on 8 June 1967, Kapp stated:

A formal theory based on the assumption that man maximizes something and then labels this something as benefit, basically leaves the aims of the activity entirely undetermined. In other words, the criteria of rationality in a new humanism have to be of a substantive nature, that is, they have to be sought and found in the degree to which they guarantee concrete conditions of life or satisfy basic existential needs. Concrete and relatively constant measures of basic needs or minimal limits of tolerance have to take the place of value functions with undetermined content (1985, p. 108).

This quote summarises well Kapp's defence of a substantive, humanistic conception of rationality, based on the centrality of a theory of human needs (bio-sociocultural needs). ${ }^{9}$ Against the logic of choice of the conventional view of rationality, focused on the revealed preferences of individuals and firms in the market (which are assumed to be optimal), Kapp's concept of rationality is founded on the definition of objective minimal requirements of human life and development (or 'minimum adequate living conditions'). These 'social minima' and their counterpart, the 'maximum tolerable levels' of disruption, would, in his view, provide 'an effective measuring rod for the definition of substantive aims and the actual progress made toward satisfying them' (Kapp 2011, p. 94). They would enable the objectification of essential human needs and of the 'costs of life and human development ${ }^{10}$ as substantive criteria for a rational use of resources.

A crucial step here is the affirmation of the centrality of human life as a first and unquestionable normative axiom-an absolute value, not an exchange value on the market - and, as such, the idea that the satisfaction of essential human needs is the ultimate goal of economic activity, the only really indisputable end. ${ }^{11}$ In Kapp's words: 'human life, development and survival are values which are worthwhile and essential to support, and to accept as unquestioned aims which need no further proof or demonstration'

\footnotetext{
${ }^{9}$ These needs would include not only elemental biological subsistence requirements, but also sociocultural (psychological and aspirational) needs, dependent on interpersonal relations, such as the human desire for self-affirmation and selfesteem.

${ }^{10}$ We should note here the proximity of Kapp's terms to F. Perroux's coûts de I'homme (Perroux 1964 [1961]), and in fact they reflect the latter's acknowledged influence. See Kapp $(2011$, p. 89) and, on the relationship between Kapp and Perroux, Frigato (2010).

${ }^{11}$ Kapp fully rejected the standard means-ends dichotomy (see Kapp 2011, pp. 27-28; 1965a, pp. 57-64).
} 
(ibid, p. 89; emphasis added). All this, according to Kapp (1976, p. 538), translates into a social and moral imperative to reduce human suffering and 'is indeed the only premise' that a substantive, humanistic economics would need to make (Kapp 2011, p. 89).

Of course, all this would not dispense with the determination of priorities (which entails choices, evaluations of conflicting interests and goals, and compromises) and a technical work of definition of the objective criteria about what is necessary and essential for human life and development. Those criteria, according to Kapp, must be 'scientifically substantiated' (1965b, p. 308) and 'empirically ascertained' (1969, pp. 335-336). This would involve the construction of social and ecological indicators and, more broadly, a new and comprehensive system of social accounting necessary for the definition of objectives and the choice of the courses of action to follow.

\subsection{The problem of valuation}

The second major aspect of Kapp's rebuttal of Beckerman's attack dealt with the latter's conventional approach to the valuation of social costs based on money values and price indicators. The conventional perspective is summarised well in this statement:

Money is just a convenient measuring rod.... Without ... monetary measurement, we have little idea of how much of a good to provide or how much of a bad to remove. If we can measure everything in money terms we can adopt a simple rule: Maximize (BenefitsCosts) ... Like it or not, any decision implies a monetary valuation ... The necessity to choose entails a monetary evaluation (Pearce 1978, pp. 2-3; original emphasis).

Monetary valuation is here assumed as constituting no more than a pragmatic requirement. Beckerman fully subscribes to this perspective.

In Kapp's view, although it is possible to attribute monetary values to environmental damage, this is inappropriate, because monetary criteria 'do not evaluate the characteristics which define the quality of the environment and its potentially negative impact on human health, human well-being and human survival' (1972, p. 26). Social costs and values were, he thought, incommensurable. Moreover, market prices do not reflect the true relative importance of needs, and business costs do not represent the total costs of production (that is, the relative opportunity costs). Hence, valuation of social costs based on market prices and monetary criteria, such as the principle of willingness to pay or willingness to accept compensation based on those prices, would not provide a sound basis for the evaluation of the desirable courses of action. Other methods of assessment were needed.

In line with his defense of a substantive view of rationality (and of his above-mentioned concept of social minima as an effective measuring rod of substantive aims and the actual progress made toward satisfying them), he suggested 'a direct social evaluation (at the political level) of essential human needs and their relative social importance and the real costs evaluated in terms of available, unutilised and potential resources' (Kapp 1974, p. 136). His proposal was that, instead of exchange values, social use values ('values which are socially, i.e. politically, appraised and determined' (ibid)) would guide the process of production and allocation, which of course would entail the set-up of the necessary institutional arrangements.

Kapp (ibid, pp. 36-39) explicitly linked this approach to the Marxist idea of measuring real wealth on the basis of the 'useful effects' of goods and services and the quantity of 
labour required to produce them (Engels) or free disposable time (Marx). He also refers to Otto Neurath, Max Weber and, more recently, the Marxists Charles Bettelheim and Paul Sweezy.

In a nutshell, while Beckerman fully relies on monetary valuation, Kapp emphasizes the idea of collectively (and politically) determined social goals and targets based on social use value considerations.

\section{Intellectual exchange for what?}

The gulf separating Kapp from Beckerman's views on rationality and valuation could not be deeper. Anyway, we may ask: why did Beckerman not respond to Kapp's arguments? And why did Kapp's theory of social costs become gradually set aside from the mainstream conversation on this topic?

The exposition in the two previous sections provides the basis for this hypothesis: that the silence surrounding Kapp's work was, above all, due to his contrary approach to the analysis of social costs (how social costs are conceived and, theoretically and practically, dealt with); to the vision and mode of thought he espoused; and to his views on the nature and scope of economic analysis more broadly. Beckerman (and mainstream economists in general) would have been unwilling (and even unable) to engage constructively with Kapp's arguments and language. Kapp did not 'think like an economist' and he could only become an outsider in the discussion of social costs. Of course, this is merely conjectural.

As already noted, it might be argued that some kind of neoliberal, market fundamentalist bias against Kapp's radical critique of the system of business enterprise is the primary cause of his displacement from the mainstream discourse on social costs. Frank Knight's (1951, p. 234) allusion to 'socialistic critique and propaganda' regarding Kapp's reflections on social values is suggestive of that bias. But an exclusively political-ideological explanation of Kapp's marginalisation from the current conversation on social costs would certainly be incomplete and partial. As the history of economic thought clearly shows:

dissent in the [economics] profession goes beyond ideology. Dissenters in the profession can come from a radical or liberal or conservative framework. What they seem to have in common is a dissatisfaction with economics as it is presently practised, how it explains the world, and the type of questions the typical economist asks (Holt and Pressman 1998, p. xi).

Ideology, understood as a set of political and economic ideas, beliefs and values, is insufficient to explain Kapp's exclusion.

A clarification of the meaning attributed to ideology is warranted. The concept is contested within the literature. I subscribe to Lawson's (2012) conceptualisation. As he suggests, one may understand ideology either as (i) a set of background ideas and beliefs, based on unquestioned and widely accepted preconceptions usually regarded as 'neutral', forming a sort of 'common sense', or (ii) a set of intentionally conceived and/ or employed ideas to justify, preserve or reinforce a desired goal or state of affairs through concealing or misrepresenting the nature of reality.

Ideology is usually associated with political or economic ideas (market fundamentalism, neoliberalism, socialism, etc.), and it is to this particular understanding that I refer as a political-ideological explanation of Kapp's marginalisation. The term propaganda 
that Knight used in his review of Kapp's book (as opposed to science) goes in this direction. But Knight's (1951) critique of Kapp for not considering the 'costs of eliminating costs' (p. 234) and, more explicitly, the arguments put forth by Beckerman in his polemical article against Kapp-all of them related to central features of conventional economicspoint to profound differences in character between Kapp's and the conventional approaches to social costs. They have to do with the metatheoretical foundations of the discipline. Consequently, an explanation focused on those different metatheoretical foundations is required. Of course, this is not incompatible with Lawson's (2012) conceptualisation, as above, of the term ideology, which can also be applied to matters of science and its method.

Beckerman's critique and Kapp's rebuttal, as already stated, clearly establish the deep gulf between Kapp and the standard approach. In addition to the obvious theoretical departures, the Kapp-Beckerman dispute exposed significant differences in vision-or worldviews - and modes of thought, in the conceptions of the nature and scope of economic analysis and in how economic problems are conceived and dealt with.

Economic reasoning, as in any other field of knowledge, presupposes a set of representations and ideas (beliefs and convictions) about the nature of the reality that is the object of study, the way the world works (Mäki 2001), and the relationship of theoretical constructs with the real world to which they are intended to apply. It presupposes a vision of reality (or worldview) - what Schumpeter (2006 [1954], p. 39) called the 'preanalytical cognitive' stage-which includes widely shared, even if unarticulated, 'political hopes and fears, social stereotypes, and value judgments ... that infuse all social thought' (Heilbroner and Milberg 1995, p. 4). ${ }^{12}$ The vision of reality 'sets the stage and peoples the cast for social inquiry' (ibid). ${ }^{13}$

Theoretical work is, to a significant extent, founded on such a vision of reality. In addition, it also entails a particular way of thinking, a 'mode of thought' (Dow 1996, p. 10; 2002, p. 164). This includes the way judgement is exercised, both regarding how arguments and theories are built, articulated and presented, and how we assess an argument as good or bad, and react to the arguments of others. The mode of thought conditions the language we privilege in our work (for example, mathematics, verbal analysis), the connections we establish (or forget), the methods and techniques we prioritise or find admissible, and, ultimately, the approach espoused.

I hypothesise that the theoretical differences separating Kapp's work from the economics mainstream are strongly rooted in their different ontological presumptionsvisions or worldviews - and modes of thought, which generate different understandings about how economic analysis is conceived and pursued. ${ }^{14}$ Kapp's worldview and mode of thought are totally disconnected from those of conventional mainstream economics. Against the mainstream reductionist, closed-systems approach, based on the conventional model of homo economicus, all his work has been developed upon an open-systems

\footnotetext{
${ }^{12}$ These preconceptions can be more or less structured, more or less conscious, more or less explicitly assumed, but they are always an inevitable part of the scientific endeavour.

${ }^{13}$ Such a vision of reality conditions the selection of problems to investigate, how these are conceived and analyzed, the selection of relevant variables and even the research methods we choose, opening an ontological window to the world at the same time that it establishes, at least in part, a set of restrictions - a kind of Buchanan's 'constitutional framework' in the context of which admissible/prohibited heuristics (and inclusions/exclusions) are considered and research programmes defined (Mäki 2001, p. 5).

${ }^{14}$ Although distinct, worldview and mode of thought are closely correlated.
} 
approach to a humanistic social knowledge, which sought fully to integrate all dimensions of economic life (natural and social) and was structured on a broader bio-cultural concept of the human being (Kapp 1961, 1985).

It is these different ontological presumptions and modes of thought, I contend, that are the primary reason for the gradual disappearance of Kapp's theory from the mainstream conversation on social costs. As Dow (2002, p. 165) argues, there is considerable scope for economists to talk past each other when they have different understandings of how the world is, speak different languages and think in different ways. In extreme cases this may result in full rejection of any engagement with conflicting perspectives (Chick 1995). This is the case with Kapp's theory of social costs.

Contrary to the conventional view that social costs are involuntary, exceptional and undesirable side effects of a main activity, which can often be corrected by ex post measures, social costs are conceived by Kapp as a pervasive and inherent, built-in consequence of the system of business enterprise, calling for ex ante institutional changes. Kapp's contrary approach manifests itself in various additional respects, both in terms of the character of social costs (and how the problem is conceived) and how the theoretical and practical problem of social costs is dealt with.

In summary:

(1) Social costs are a systemic problem of capitalism rather than a problem of individual markets.

(2) Social costs constitute a violation of social rights rather than a problem of the nonassignment of property rights.

(3) Power and distributive issues are crucial.

(4) Analysis of social costs is to be engaged assuming that they are the outcome of complex, cumulative processes of interdependence, and not within the framework of equilibrium analysis.

(5) Human needs and social efficiency (the best possible performance of the overall economy from the perspective of a society's values), rather than Pareto efficiency, are the relevant goals to be pursued. Considering human life, development and survival as unquestioned aims which need no further proof or demonstration is the assumed fundamental normative axiom.

(6) Social use values (values of things to society), appropriate socio-ecological indicators alternative to the conventional ones (minimum adequate living conditions or social minima) and a new comprehensive system of social accounts, provide 'an effective measuring rod for the definition of substantive aims and the actual progress made toward satisfying them' (Kapp 2011, p. 94). Social costs and values are incommensurable. Market prices (values in society) and the sacrosanct measuring rod of money do not provide a sound basis for the evaluation of the desirable courses of action to follow. $^{15}$

(7) Social costs are, in the end, a societal issue involving democratic participation and collective deliberation in addition to technical expertise. They constitute a political

\footnotetext{
${ }^{15}$ The distinction between values to society and values in society (Kapp 1950, p. 256) was borrowed from J. Maurice Clark: 'The ultimate problems in which humanity is interested are not those of social value in the sense of "value in society" as registered by market standards. Men are interested in the values of things to society' (2009 [1936], p. 61).
} 


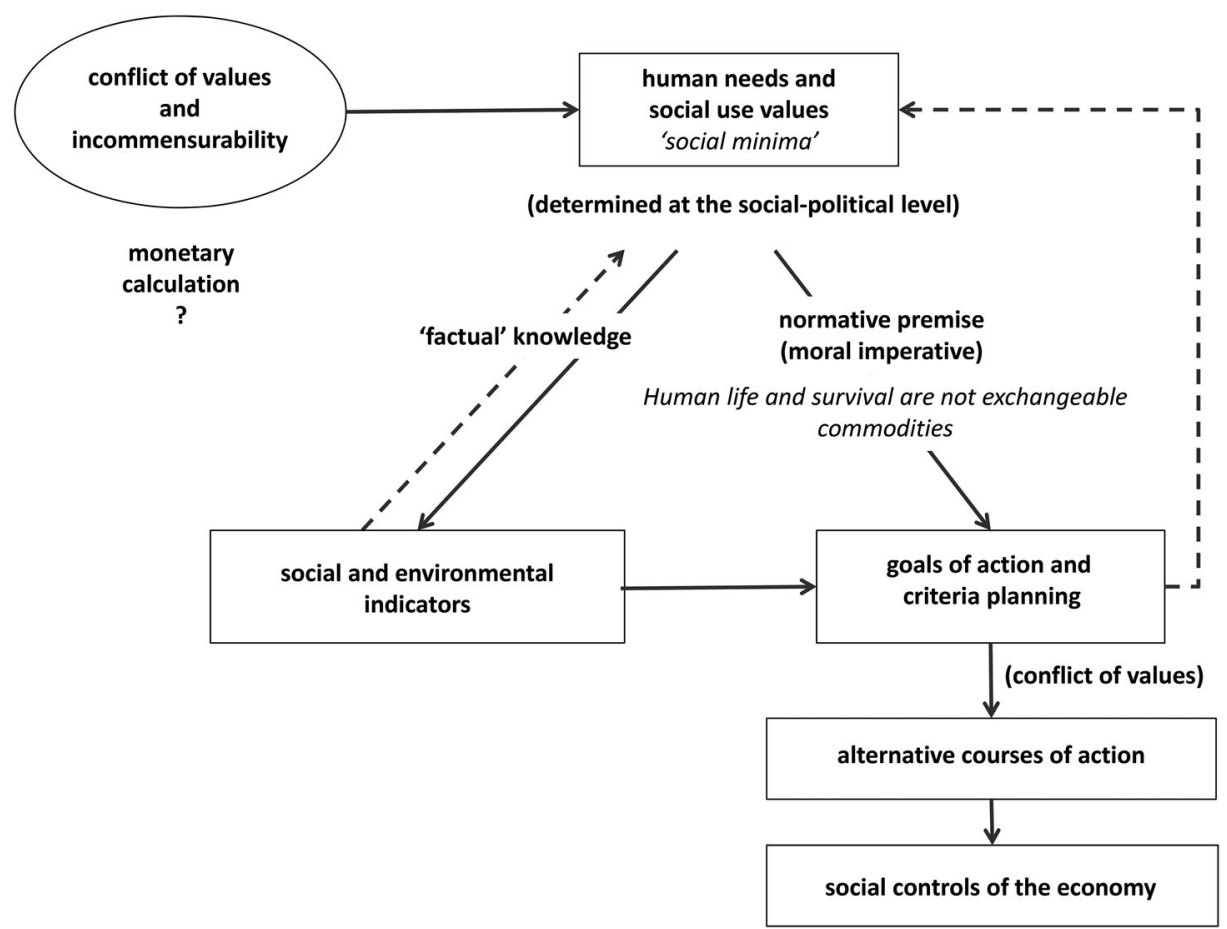

Figure 1. Kapp's general (deliberative) framework.

economy problem, and are not reducible to a technical (economic) issue to be solved by experts.

Figure 1 illustrates Kapp's Figure 1 position.

For all the aspects discussed, the differences relative to the mainstream are so deeprooted as to preclude (or, at least, significantly hinder) the possibility of a constructive dialogue. Divergences are located at the (Lakatosian) hard-core level. They are, to use Backhouse's (2004, pp. 263-264) expression and categorisation, 'beyond the pale', constituting 'an extreme form of dissent', that is, a disagreement that does not become the subject of controversy but is simply ignored or dismissed. It entails insiders and outsiders. Kapp, according to the conventional view-expressed in terms of an adherence to Mankiw's (2004) 10 basic principles (or unifying central ideas) of modern economics ${ }^{16}$ or Beckerman's formal logic of choice, economic calculation based on market prices and the principle of willingness to pay or accept compensation of welfare economics-did not 'think like an economist'. Answering Kapp's rebuttal, Beckerman might have considered futile.

\footnotetext{
${ }^{16}$ Mankiw's (2004) 10 principles are as follows: (1) people face trade-offs; (2) the cost of something is what you give up to get something; (3) rational people think at the margin; (4) people respond to incentives; (5) trade can make everyone better off; (6) markets are usually a good way to organise economic activity; (7) governments can sometimes improve market outcomes; (8) a country's standard of living depends on its ability to produce goods and services; (9) prices rise when the government prints too much money; (10) society faces a short-run trade-off between inflation and unemployment. For a critique of the significance and implications of these principles, see Caldas, Neves, and Reis (2011).
} 
The former's arguments did not deserve to be taken seriously. Kapp and Beckerman were not part of the same scientific community; they did not share the same culture. Their views correspond to 'incommensurable ways of seeing the world and of practicing science in it' (Kuhn 1996 [1962], p. 4). Their problems and standards are not the same, the relationships they establish are different and they work in different worlds (they 'see different things when they look from the same point in the same direction ... and they see them in different relations one to the other' (ibid, pp. 148-150). Each worked within a different paradigm. $^{17}$

It is thus not difficult to understand the conspiracy of silence surrounding Kapp and many other heterodox critics of the orthodoxy. It is to be understood, I suggest, primarily as a consequence of his rather different way of approaching economics as a social science. Kapp could only be an outsider in the discussion on social costs.

\section{So what?}

Disagreement within the social science discipline of economics may occur at various levels: ontological, methodological, theoretical, empirical results or practical/policy recommendations. It may range from some minor aspect of accepted orthodoxy to challenges to the very foundations and character of the discipline.

Kapp's theory of social costs was part of a broader intellectual project to rebuild the foundations and substance of economic analysis (see the editorial introduction to Kapp 2011). As such, it posed a challenge to conventional contemporary economics by questioning its longestablished foundations of (formal) rationality, choice, efficiency and valuation.

Of course, it may be argued that this does not preclude the possibility of dialogue. ${ }^{18}$ However, the eventual conspiracy of silence against Kapp's theory by mainstream economists suggests that the divergences are so deeply grounded that no dialogue is possible. I suggest that they are located at the metatheoretical hard-core level.

Economics is a 'multiparadigm discipline' (Dow 2008, p. 11), a bundle of conversations, but, as Klamer (2007) maintains, 'talking across them is problematic if not impossible'. Lee (2013, p. 3), for example, stated that it is near impossible to find a way to have an honest theoretical engagement between mainstream economics [sic] qua economists and those who are interested in developing an alternative to mainstream economics'. Berger (2016, p. 2), in turn, suggests that, today, Kapp would reject any possibility of pluralism in economics that included neoclassical economics (an anything goes approach, according to Berger). But why, then, would Kapp bother to reply to Beckerman?

As Stilwell (2013, p. 11), among others, claims, 'mainstream economists simply ignore the contributions of radical critics. Indeed, almost by definition, people who do not subscribe to the standard principles of the subject are not regarded as "economists".' Recent

\footnotetext{
${ }^{17} \mathrm{~A}$ paradigm is here understood as both an intellectual and a sociological category. It refers to the shared beliefs of a scientific community about fundamental aspects of their discipline (subject matter and understanding of the nature of reality, the tools and language considered suitable to build knowledge about it, and the commonly held values and appraisal criteria subscribed to assess scientific quality). A paradigm represents a specific way of thinking and a set of institutional arrangements within which scientific activity occurs. In so far as scientists working within different paradigms 'see different things and see them in different relations one to the other', some sort of paradigm shift (like a gestalt switch) must take place before communication between them can occur. (See Dow 2002, 2008; Bernstein 1983).

${ }^{18}$ As Bernstein $(1983$, p. 108) emphasises, 'the core of the incommensurability thesis ... is not closure and being encapsulated in self contained frameworks but the openness of experience, language, and understanding'.
} 
developments in mainstream economics show that, although different theoretical approaches and methods are admitted (to a certain extent), diversity at the level of methodology, or approach, is considered to be 'beyond the pale' (Dow 2008).

The increasing monism in terms of methodological approach has ... allowed the emergence of a plurality of theoretical approaches, using different subsets of formal techniques. But at the same time, it has created a dualistic divide between theories which conform to these norms of development and expression and those which do not, discouraging mutual understanding and communication. There is an asymmetry in that, for mainstream economics, the formalist methodological approach defines the discipline (Dow 2007, p. 454).

One critical consequence is that alternatives that do not accord with such canon become excluded as mere ideology, not economics.

Constructive dialogue, the Kapp-Beckerman dispute shows, requires that ontological presuppositions and modes of thought be shared. Yet, as Norgaard (1994, p. 84; emphasis added) rightly noted, 'our understanding of complex systems is necessarily based on multiple incongruent ways of knowing'. Hence, some form of constructive pluralism is justified.

This raises the interesting issue of where the boundaries of pluralism (or what is acceptable) in economics lie. What are the limits of dialogue? According to Backhouse (2004, p. 269), this is 'one of the most important issues in the study of the economics profession'. To this, Samuels (2006, p. 121) adds, 'how those boundaries are drawn and redrawn'. However, as Dow (2002, pp. 160-161) observes:

pluralism raises more issues than it resolves. There is clearly much room for debate, about the extent of pluralism and whether there is scope for conventional agreement about its scope, what range of methods is suggested by different ontologies, how different types of knowledge should be combined, about the role of mathematics, which type of mathematics, and so on.

Tackling those issues is beyond the scope of this article but does provide fertile ground for an important debate within the social science discipline of economics.

\section{Disclosure statement}

No potential conflict of interest was reported by the author.

\section{ORCID}

Vitor Neves (D) http://orcid.org/0000-0002-3394-5866

\section{References}

Aslanbeigui, N., and S. Medema. 1998. 'Beyond the Dark Clouds: Pigou and Coase on Social Cost.' History of Political Economy 30 4: 601-625.

Ayres, R., and A. Kneese. 1969. 'Production, Consumption, and Externalities.' The American Economic Review 59 3: 282-297.

Backhouse, R. 2004. 'A suggestion for clarifying the study of dissent in economics.' Journal of the History of Economic Thought 26 2: 261-271.

Beckerman, W. 1972. 'Environmental policy and the challenge to economic theory.' Social Science Information 11 1: 7-15.

Berger, S. 2012. 'The discourse on social costs. Kapp's 'impossibility thesis' vs. neoliberalism.' In Social Costs Today: Institutional analysis of the present crises, edited by P. Ramazzotti, P. Frigato, and W. Elsner. London and New York: Routledge. 
Berger, S. 2013. 'The Making of the Institutional Theory of Social Costs: Discovering the K. W. Kapp and J. M. Clark Correspondence.' American Journal of Economics and Sociology 72 5: 1106-1130.

Berger, S. 2016. 'Introduction.' In The Heterodox Theory of Social Costs, edited by S. Berger. London and New York: Routledge.

Bernstein, R. 1983. Beyond Objectivism and Relativism: Science, Hermeneutics, and Praxis. Philadelphia: University of Pennsylvania Press.

Caldas, J., V. Neves, and J. Reis. 2011. 'Why is economics so fragile?' Revue de la régulation [online] $91^{\text {st }}$ semester. https://regulation.revues.org/9244.

Chick, V. 1995. 'Order out of caos' in Economics?' In Keynes, Knowledge and Uncertainty, edited by S. Dow and J. Hillard. Cheltenham: Elgar.

Clark, J. M. 2009 [1936]. Preface to Social Economics: Economic Theory and Social Problems, organized by M. Abramovitz and E. Ginzberg. New Brunswick: Transaction Publishers.

Coddington, A. 1970, April. 'The Economics of Ecology.' New Society 9: 595-597.

Dow, S. 1996. The methodology of macroeconomic thought: A conceptual analysis of schools of thought in economics. Cheltenham: Edward Elgar.

Dow, S. 2002. Economic methodology: An inquiry. Oxford: Oxford University Press.

Dow, S. 2007. 'Variety of Methodological Approach in Economics.' Journal of Economic Surveys 21 3: 447-465.

Dow, S. 2008. 'A Future for Schools of Thought and Pluralism in Heterodox Economics.' In Future Directions for Heterodox Economics, edited by J. Harvey and R. Garnett Jr.. Ann Arbor: The University of Michigan Press.

Elsner, W., P. Frigato, and P. Ramazzoti, eds. 2006. Social Costs and Public Action in Modern Capitalism: Essays inspired by Karl William Kapp's Theory of Social Costs. London and New York: Routledge.

Franzini, M. 2006. 'Social Costs, Social Rights and the Limits of Free Market Capitalism: A Rereading of Kapp.' In Social Costs and Public Action in Modern Capitalism: Essays inspired by Karl William Kapp's Theory of Social Costs, edited by W. Elsner, P. Frigato, and P. Ramazzotti. London and New York: Routledge.

Frigato, P. 2010. 'The silent removal of the theory of social costs from current 'old' institutional perspectives on the firm. Some reflections inspired by Kapp and Perroux.' In Humanism and Religion in the History of Economic Thought, Selected Papers from the $10^{\text {th }}$ Aispe conference, edited by D. F. Parisi and S. Solari. Milano: Franco Angeli.

Gerber, J.-F., and R. Steppacher, eds. 2012. Towards an Integrated Paradigm in Heterodox Economics: Alternative Approaches to the Current Eco-Social Crises. Basingstoke: Palgrave Macmillan.

Heilbroner, R., and W. Milberg. 1995. The Crisis of Vision in Modern Economic Thought. Cambridge: Cambridge University Press.

Holt, R., and S. Pressman, eds. 1998. Economics and its Discontents: Twentieth Century Dissenting Economists. Cheltenham: Edward Elgar.

Kapp, K. 1950. The Social Costs of Private Enterprise. Cambridge, MA: Harvard University Press (paperback edition published by Schocken Books, New York, 1971 with a new introduction).

Kapp, K. 1961. Toward a Science of Man in Society: A Positive Approach to the Integrations of Social Knowledge. The Hague: Martinus Nijhoff.

Kapp, K. 1963. 'Social Costs and Social Benefits - A Contribution to Normative Economics.' In Probleme der normativen Ökonomik und der wirtschaftspolitischen Beratung, edited by E. Beckerath and H. Giersch. Berlin: Duncker and Humblot.

Kapp, K. 1965a. 'Economic Development in a New Perspective: Existential Minima and Substantive Rationality.' Kyklos 18 1: 49-79.

Kapp, K. 1965b. 'Social Economics and Social Welfare Minima.' In Towards a Sociology of Culture in India, Essays in Honor of Dr. D. P. Mukerji, edited by T. K. N. Unnithan et al.. New Delhi: Prentice Hall of India. Accessed March 9, 2011. http://www.kwilliam-kapp.de/documents/ INDIAPDF.pdf

Kapp, K. 1969. 'On the Nature and Significance of Social Costs.' Kyklos 22 2: 334-347. 
Kapp, K. 1970. 'Environmental Disruption and Social Costs: a Challenge to Economics.' Kyklos 23 4: 833-848.

Kapp, K. 1972. 'Social costs, neo-classical economics, environmental planning: A reply.' Social Science Information 11 1: 17-28.

Kapp, K. 1974. Environmental Policies and Development Planning in Contemporary China and Other Essays. Paris/The Hague: Mouton.

Kapp, K. 1976. 'The Open-System Character of the Economy and its Implications.' In Economics in the Future, edited by K. Dopfer. London: The Macmillan Press.

Kapp, K. 1977. 'Environment and Technology: New Frontiers for the Social and Natural Sciences.' Journal of Economic Issues 11 3: 527-540.

Kapp, K. 1978 [1963]. The Social Costs of Business Enterprise, second edition of The Social Costs of Private Enterprise, extensively revised and rewritten. Nottingham: Spokesman.

Kapp, K. 1983 [1965]. 'Social Costs in Economic Development.' In Social Costs, Economic Development and Environmental Disruption, edited and with an introduction by J. Ullmann. Lanham: University Press of America.

Kapp, K. 1985. The Humanization of the Social Sciences, edited by J. Ullmann and R. Preiswerk. Lanham: University Press of America.

Kapp, K. 2011. The Foundations of Institutional Economics, edited by S. Berger and R. Steppacher. London: Routledge.

Kapp, K. 2016. The Heterodox Theory of Social Costs, edited by S. Berger. London and New York: Routledge.

Klamer, A. 2007. Speaking of Economics: how to get in the conversation. London and New York: Routledge.

Knight, F. 1951. 'Book review of K. W. Kapp's The Social Costs of Private Enterprise.' In The ANNALS of the American Academy of Political and Social Science, 233-234. Accessed March 9, 2011. http://ann.sagepub.com/content/273/1/201.citation.

Kuhn, T. 1996 [1962]. The Structure of Scientific Revolutions. 3rd ed. Chicago and London: The University of Chicago Press.

Lawson, T. 2012. 'Mathematical Modelling and Ideology in the Economics Academy: competing explanations of the failings of the modern discipline?' Economic Thought: History, Philosophy, and Methodology 1: 3-22. Accessed April 22, 2015. http://et.worldeconomicsassociation.org/ files/ETLawson_1_1.pdf.

Lee, F. 2013. 'Editor's Introduction.' In Studies in Economic Reform and Social Justice: Social Costs of Markets and Economic Theory, edited by F. Lee. West Sussex: Wiley.

Mäki, U. 2001. 'The way the world works (www): Towards an ontology of theory choice.' In The economic world view: Studies in the ontology of economics, edited by U. Mäki. Cambridge: Cambridge University Press.

Mankiw, N. 2004. Principles of Economics. 3rd ed. Mason, Ohio: Thomson South-Western.

Mirowski, P., and Plehwe, D. 2009. The Road from Mont Pèlerin: the making of the neoliberal thought collective. Cambridge, MA: Harvard University Press.

Norgaard, R. 1994. Development Betrayed: the end of progress and a coevolutionary revisioning of the future. London and New York: Routledge.

Pearce, D. 1978. 'Introduction.' In The Valuation of Social Cost, edited by D. Pearce. London: George Allen and Unwin.

Perroux, F. 1964 [1961]. L'économie du XXème siècle. 2nd ed. Paris: Presses Universitaires de France.

Ramazzotti, P., P. Frigato, and W. Elsner, eds. 2012. Social Costs Today: Institutional analyses of the present crises. London and New York: Routledge.

Samuels, W. 2006. 'Roger Backhouse on the study of dissent.' Journal of the History of Economic Thought 28 1: 119-123.

Schumpeter, J. 2006 [1954]. History of Economic Analysis. Routledge: Taylor and Francis e-Library.

Steppacher, R., B. Zogg-Walz, and H. Hatzfeldt, eds. 1977. Economics in Institutional Perspective: Memorial Essays in Honor of K. William Kapp. Toronto: Lexington Books.

Stilwell, F. 2013. 'Interview with Frank Stillwell.' World Economics Association Newsletter 31: 9-12. 